Eduvest - Journal of Universal Studies

Volume 1 Number 11, November 2021

p- ISSN 2775-3735 e-ISSN 2775-3727

\title{
THE PROMISING ETHICS AND COMPETITIVE ADVANTAGE ON HIGHER EDUCATION AS A PART OF INTERNATIONAL COLLABORATION PROGRAMS
}

Prihartono

Polytechnic Piksi Ganesha, Bandung- Indonesia

E-mail: prihartono@piksi.ac.id

\begin{tabular}{|c|c|}
\hline ARTICLE INFO & ABSTRACT \\
\hline $\begin{array}{l}\text { Received: } \\
\text { October, } 26^{\text {th }} \\
2021 \\
\text { Revised: } \\
\text { November, } 17^{\text {th }} \\
2021 \\
\text { Approved: } \\
\text { November, 19th } \\
2021\end{array}$ & $\begin{array}{l}\text { Promises ethics in service triangle context on higher } \\
\text { education can be met if performance improves superior } \\
\text { performance and be given the implications for competitive } \\
\text { advantage. The purpose of this study was to analyze and } \\
\text { determine promising ethics in service marketing triangle } \\
\text { and competitive advantage of higher education. The } \\
\text { research method used is survey method, namely } \\
\text { descriptive and explanatory. The number of respondents } \\
\text { in the study is } 330 \text { students of the polytechnic in West } \\
\text { Java, which is determined by sampling technique, which is } \\
\text { cluster proportional random sampling. The hypothesis } \\
\text { testing was done using a multivariate statistical test of } \\
\text { the Partial Least Square (PLS). The data processing was } \\
\text { done with smartPLS 2.0 programs and Statistical } \\
\text { Programs of Social Science (SPSS) for Windows. The } \\
\text { results show that: The promising ethics in service triangle } \\
\text { context and competitive advantage influence as well but } \\
\text { not quite good. The promising ethics in service marketing } \\
\text { triangle context can be met also if performance improves } \\
\text { international collaboration on higher education as well, so } \\
\text { that promises ethics can be achieved optimally and be } \\
\text { given the implications for competitive advantage of higher } \\
\text { education. }\end{array}$ \\
\hline KEYW & $\begin{array}{l}\text { Promising Ethics, Competitive Advantage, International } \\
\text { Collaboration }\end{array}$ \\
\hline
\end{tabular}

Prihartono (2021). The Promising Ethics and Competitive

Advantage on Higher Education as a Part of International

Collaboration Programs. Journal Eduvest. 1(11): 1322-1328

How to cite:

E-ISSN:

Published by:

https://greenpublisher.id/ 


\section{Prihartono}

\begin{tabular}{|c|c|}
\hline (c) (i) (?) & $\begin{array}{l}\text { This work is licensed under a Creative C } \\
\text { Attribution-ShareAlike } 4.0 \text { International }\end{array}$ \\
\hline
\end{tabular}

\section{INTRODUCTION}

The condition of higher education (PT) in Indonesia is currently facing competition not only local, but also regional and global competition. Globalization has led to competition for educational institutions that is not only local or regional, but also international. Global competition impacts in the education sector, one of the internationalization of higher education (De Wit, Deca, \& Hunter, 2015), which is manifested through the four forms, namely: (1) the opening of branches of universities in other countries (like the class extension), for example, American universities to open a branch in Asia; (2), the cooperation between the universities of the country with universities in other countries that offer degree programs, (3) lecture remotely through both print and virtual media over the internet. A number of leading universities in the United States, Europe, and Australia offers degree programs through this model, and (4), the comparative study of the quality of higher education that produces college ranking compared to some other college. The global competition will inevitably be faced by universities in Indonesia, both public and private (Ng, 2012).

Competition faced by the private universities will be heavier and tighter. Currently in Indonesia there are about 3147 colleges with 15,819 courses. Of these, as many as $15.6 \%$ or 491 colleges located in West Java. With that number, West Java has the highest number of colleges in Indonesia. Recent data, in 2019, of 115 private college (PTS) in West Java nearly $40 \%$ of them in an unhealthy condition due to lack of students (LLDikti Region IV, 2011).

Competitive advantage to be owned by polytechnics should be tailored to the potential and variety of its resources. The ability to generate superior value that is deemed worthy to polytechnic believed in vocational education. Vocational education programs believed to be an option to boost the skills and practical skills according to related field; benefits, quality, product-specific attributes, events product use, the position of the competitor's product and product class classification. Thus, referring to the need to know the position of ethics in service triangle context on higher education, the identification of empirical support for the general theory of marketing ethics and ethical phenomenon, competitive advantage can be a part of international collaboration programs.

Grand Theory used in this study is the theory of consumer behavior. (Rajab, Rahman, \& Shaari, 2011) argue that consumer behavior is an individual activity in finding information, purchasing, using something, evaluating against products and services in the hope of satisfying his desire. The essence of consumer behavior includes two elements, namely (1) the decision making process (decision process) and (2) the act or physical activity. Everything involves individuals in assessing, acquiring and using goods and services.

Middle Range Theory or the theory used in this study is the theory of Strategic Marketing for educational services with the applicable theories (Applied Theory) relating to services marketing mix theory, the theory of competitive advantage, and the theory of marketing ethics. According to (Kotler \& Keller, 2012) educational institutions realize that they have a lot of marketing issues, ranging from the declining number of students who enroll, small grants for education and other sources of income, while operating costs continue to rise. It is reminded that the educational institutions are also thinking about the reliance on markets where they are. Many educational institutions are in the face of 
changing expectations and needs of students, while increasing competition to acquire new students and new funding sources.

The results which are relevant to the performance of product attributes can be summarized as follows: (1) (Iversen \& Lurås, 2002) concludes that one way to achieve competitive advantage is by continuing to produce and elaborate synergies between the assets and facilities owned by the company, because the use of assets provides efficiency, when the company has different products with competitors' assets, it will be different, (2) (Littel \& Orth, 2013), concludes that the differentiation of the packaging gives a unique impression on the product, (3) (Ali, 2020) concludes that organizational capabilities include information, product development, relationship building associated with competitive advantage, (4) (Abdullah \& Rosliyati, 2020), concludes that the product strategy and value creation affect competitive advantage.

Promises, in the view of the promises ethics, are a specific obligation that forms engagement with other parties who receive the promises. This engagement morally raises obligation that the promises made by others should be kept. Berry stressed that the basis for maintaining relationship in services is the promises that has been made to the customer. For service providers it has implications for the three activities namely make unrealistic promises, keep and fulfill the promises at the time of the delivery the services with an effort to allow the promises on the service system being built to meet those promises (Mohr \& Bitner, 1995). The three important marketing activities to do the efforts are external marketing, interactive marketing, and internal marketing. The concept shows a linkage group that work together to develop, promote and deliver services that are referred to as key actors.

Various studies relevant to the promises ethics can be summarized as follows: (1) (Mohr \& Bitner, 1995) concludes that the activities of the company to attempt to meet promises has been given to the customer has something to do with the skills, abilities, motivation and system, (2) (Darroch, Miles, Jardine, \& Cooke, 2004) concludes that the commitment of providers ethics in delivering the promises and sense of responsibility effect on the willingness to fulfill the promises, (3) (Schwepker \& Schultz, 2015) concludes that honesty is a part of fairness and openness, and communicating it properly with the aim of creating trust for the other party, (4) (Sferrazzo \& Ruffini, 2021) asserts that ethical policies relating to the development of ethics in the organization that enable organizations to carry out their responsibilities, (5) (Taufani, 2010) concludes that the most important ethical aspects that play a role in making promises is the clarity in the promises delivery. The most important ethical aspects that play a role in enabling the most promises is the seriousness and responsibility in providing the system for students.

\section{RESEARCH METHOD}

This research is descriptive and verification conducted in 2019 to students in polytechnics in West Java. The unit of analysis in this study was the students of the polytechnic. In this study, it was used a range of time (time horizon) which was one shoot with the type of cross-section data. The descriptive hypotheses test used Weighted Mean Score / WMS. In the verification study with the approach in modeling and solution techniques to be used as a tool of analysis was a method of Structural Equation Modeling (SEM) based on a variant or a component, namely the Partial Least Square (PLS).

The population in this study is the overall characteristics of the study variables perceived by the students of the Polytechnic. The unit of analysis is 31 Polytechnics, while the unit of observation is the active students at the private polytechnic in West Java 


\section{Prihartono}

The sample size was determined in accordance with the number of samples required for the variant or component-based structural equation model (Structural Equation Model / SEM), namely Partial Least Square (PLS). The sampling method used is proportional Simple Cluster Random Sampling Method (Borucki et al., 2010) to all students of a private polytechnic as the population unit. From the results of these calculations, the sample size in this study is 385 respondents.

\section{RESULT AND DISCUSSION}

Regarding to the right of refusal (the right not to respond on statements) of the respondents, then there should be 385 questionnaires collected, the fact is only 330 copies collected, so the number of questionnaires that can be processed is only 330 copies.

Here are responses / perceptions of the respondents on Promises Ethics in service marketing triangle context and Competitive Advantage.

Table 1 Recapitulation of Promises Ethics in service marketing triangle context

\begin{tabular}{rllll}
\hline Dimention & $\begin{array}{c}\text { Actual } \\
\text { Score }\end{array}$ & $\begin{array}{c}\text { Ideal } \\
\text { Score }\end{array}$ & WMS (\%) \\
\hline 1. & Making Promises Ethics & 12,150 & 18,000 & 67.5 \\
\hline 2. & Delivering Promises Ethics & 12,000 & 18,000 & 66.7 \\
\hline 3. & Enabling Promises Ethics & 18,410 & 27,000 & 68.19 \\
\hline Total & & $\mathbf{4 2 , 5 6 0}$ & $\mathbf{6 3 , 0 0 0}$ & $\mathbf{6 7 . 4 5}$ \\
\hline
\end{tabular}

Table 2 Recapitulation of Competitive Advantage Dimension

\begin{tabular}{llll}
\hline Dimention & $\begin{array}{c}\text { Actual } \\
\text { Score }\end{array}$ & $\begin{array}{c}\text { Ideal } \\
\text { Score }\end{array}$ & WMS (\%) \\
\hline 1. Service Unique & 5,004 & 7,500 & 66.72 \\
\hline 2. Benefit & $4, .190$ & 6,000 & 69.83 \\
\hline 3. Scarifies & 3,900 & 6,000 & 65.00 \\
\hline 4. Quality Performance & 1,880 & 3,000 & 62.67 \\
\hline 5. Innovation & 1,880 & 3,000 & 62.67 \\
\hline 6. Integrity and Responsibility & 2,054 & 3,000 & 68.47 \\
\hline Total & $\mathbf{1 0 , 1 2 2}$ & $\mathbf{1 5 , 0 0 0}$ & $\mathbf{6 5 . 8 9}$ \\
\hline
\end{tabular}

Description:

PE1 $=$ Making promises Ethics

PE2 $=$ Delivering promises Ethics

PE3 = Enabling promises Ethics

$\mathrm{CA} 1=$ Service Unique

$\mathrm{CA} 2=$ Benefit

$\mathrm{CA} 3=$ Price

CA4 $=$ Quality performance

CA5 $=$ Innovation

CA6 = Integrity and Responsibility

The Influence of Promises Ethics in Service Marketing Triangle Context on Competitive Advantage

The fourth influence of promises ethics in the service marketing triangle context on competitive advantage, is shown ; 


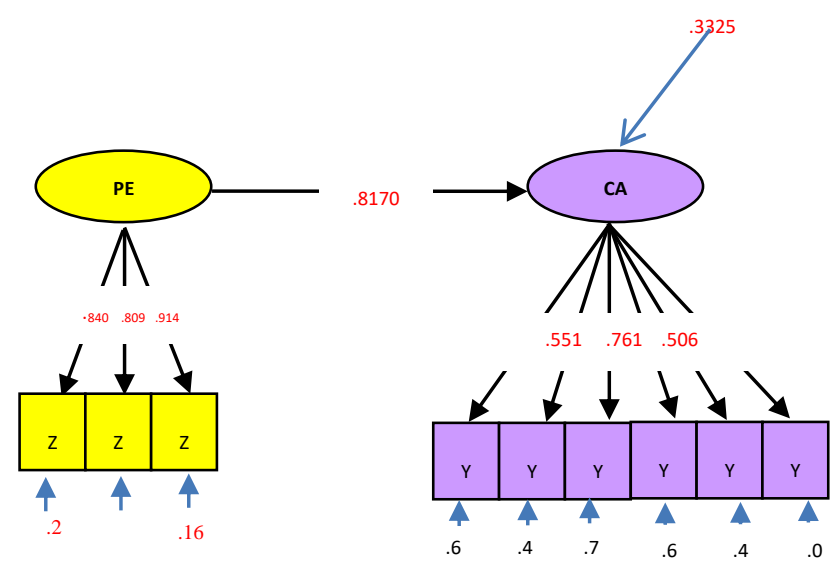

Figure 1 Line Diagram of the Influence of Promises Ethics on Competitive Advantage

The results of statistical calculations using SmartPLS 2.0 program, shows the influence of competitive advantage on the promises ethic in service marketing triangle context, in detail it can be seen as below;

Table 3 Test Result of the Influence of Promises Ethics on Competitive Advantage

\begin{tabular}{lllll}
\hline Variable & $\begin{array}{l}\text { Coefficient } \\
\text { Influence }\end{array}$ & of $\mathrm{T}_{\text {observed }}$ & $\alpha$ & Conclusion \\
\hline Promises Ethics (PE) & 0.6675 & 25.673 & 0.05 & Significant \\
\hline Direct Influence & Indirect Influence & \multicolumn{2}{l}{ Total Influence } \\
\hline 0.6675 & 0 & & 0.6675 & \\
\hline
\end{tabular}

According to researcher the positive value reflects that promises ethics actually has a positive and significant influence on competitive advantage.

To improve promises ethics as a part of competentitive advantage in higher education, it should make collaboration both national and international as well. In Indonesia, since 1999, the National Committee on Corporate Governance (KNKCG) has issued guidance Good Corporate Governance (GCG) first and perfected in 2001. The principle of good corporate governance, namely: Transparency, independence, accountability, responsibility, equality and fairness.

1. Transparency ; The basic principle : to maintain objectivity in doing business, companies must provide material and relevant information in a way that is easily accessible and understood by stakeholders.

2. Accountability ; The basic principle: the company (including colleges) have to be accountable for its performance in a transparent and fair.

3. Responsibility ; The basic principle: the company (including colleges) have to comply with statutory regulations and fulfill its responsibility to society and the environment that can be maintained in the long-term sustainability of the business and gain recognition as a good corporate citizen.

4. Independency ; The basic principle : the company must be managed independently so that each organ of the company not dominate the other and can not be interfered with by other parties.

5. Fairness ; The basic principle: in carrying out its activities, the company must 


\section{Prihartono}

always consider the interests of shareholders and other stakeholders based on the principles of equality and fairness.

Application of the values of good corporate governance in higher education can be internalized into the college culture, so that it becomes a system that strengthen competitive advantage. The purpose of the policy of good corporate governance in higher education is that parties play a role in running the college management to understand and perform the functions and role of appropriate authority and responsibility. Parties whose role includes the Board of Trustees, the Board of Trustees, Senate, Rector and the Vice Rector, the Committee (if any), Bureau Chief, Dean and the Vice Dean, The Structural Officials, Faculty, Head of Unit and Employees.

\section{CONCLUSION}

Based on the explanation above, it can be concluded as follows ; Promises ethics in the context of service marketing service directly influence the competitive advantage $(66.75 \%)$. And to make more quality in organizing higher education, it should do any programs both nationally and internationally as well. The socio-cultural benefits, collaboration could be used to support the development efforts and the development of social and cultural values of the nation in the response to any form of threats, challenges, barriers, international interference, within the framework of the implementation of national development and also collaboration can be used to increase the role and image of the country in international forums and the relationship between the state and the confidence of the international community. To make collaboration, partnership and consortium also very important one to keep Promising Ethics in activities also can be used in higher education. Those are are external marketing, interactive marketing, and internal marketing. The concept shows a linkage group that work together to develop, promote and deliver services that are referred to as key actors.

\section{REFERENCES}

Abdullah, Yusuf, \& Rosliyati, Ati. (2020). The Product Market Strategy, Value Creation, And Competitive Advantages As A Determinant Factor Of Marketing Performance. Int. J Sup. Chain. Mgt Vol, 9(3), 13.

Ali, Hapzi. (2020). The Promises Ethics And Marketing Concept Strategy As A Competitive Advantage On Private Higher Education (A Survey On Perception Of Product Attributes And Promotion Mix In Indonesia). Talent Development \& Excellence, 12.

Borucki, William J., Koch, David, Basri, Gibor, Batalha, Natalie, Brown, Timothy, Caldwell, Douglas, Caldwell, John, Christensen-Dalsgaard, Jørgen, Cochran, William D., \& Devore, Edna. (2010). Kepler Planet-Detection Mission: Introduction And First Results. Science, 327(5968), 977-980.

Darroch, Jenny, Miles, Morgan P., Jardine, Andrew, \& Cooke, Ernest F. (2004). The 2004 Ama Definition Of Marketing And Its Relationship To A Market Orientation: An Extension Of Cooke, Rayburn, \& Abercrombie (1992). Journal Of Marketing Theory And Practice, 12(4), 29-38. 
De Wit, Hans, Deca, Ligia, \& Hunter, Fiona. (2015). Internationalization Of Higher Education-What Can Research Add To The Policy Debate?[Overview Paper]. In The European Higher Education Area (Pp. 312). Springer, Cham.

Iversen, Tor, \& Lurås, Hilde. (2002). Waiting Time As A Competitive Device: An Example From General Medical Practice. International Journal Of Health Care Finance And Economics, 2(3), 189-204.

Kotler, Philip, \& Keller, K. L. (2012). Marketing Management 13rd Edition. New Jersey: Perason Parentice Hall. Inc.

Littel, Sandra, \& Orth, Ulrich R. (2013). Effects Of Package Visuals And Haptics On Brand Evaluations. European Journal Of Marketing.

Mohr, Lois A., \& Bitner, Mary Jo. (1995). The Role Of Employee Effort In Satisfaction With Service Transactions. Journal Of Business Research, 32(3), 239-252.

Ng, Shun Wing. (2012). Rethinking The Mission Of Internationalization Of Higher Education In The Asia-Pacific Region. Compare: A Journal Of Comparative And International Education, 42(3), 439-459.

Rajab, Azizah, Rahman, Hamidah Abdul, \& Shaari, Roziana. (2011). The International Students'perception Towards The Education Quality. International Journal Of Social Sciences And Humanity Studies, 3(2), 49-58.

Schwepker, Charles H., \& Schultz, Roberta J. (2015). Influence Of The Ethical Servant Leader And Ethical Climate On Customer Value Enhancing Sales Performance. Journal Of Personal Selling \& Sales Management, 35(2), 93107.

Sferrazzo, Roberta, \& Ruffini, Renato. (2021). Are Liberated Companies A Concrete Application Of Sen's Capability Approach? Journal Of Business Ethics, 170(2), 329-342.

Taufani, Raga. (2010). Tanggung Jawab Bank Akibat Kerugian Diderita Oleh Nasabah. Jurnal Hukum, 18(18), 69-86. 